\title{
A Case study on Efficacy of Nasya karma with Karpasasthyadi thailam in the Management of Kaphavrutha Vata w.s.r Manyasthamba
}

\author{
Case report
}

\section{Remesh Chandran T $\mathbf{S}^{*}$, Manu $\mathbf{R}^{2}$, Sainath Pillai R ${ }^{3}$}

\author{
1. P.G. Scholar, 2. Professor, 3. PG Scholar, \\ Department of Kayachikitsa, Parul Institute of Ayurved, Parul University, P.O. Limda, Vadodara.
}

\begin{abstract}
Manyasthamba (Cervical Spondylosis) is one among the Eighty Nanathmaja Vata Vyadhi's. Due to the Nidanas (Etiology) like sleeping during day time, sitting and standing on irregular postures, constantly gazing upwards. Avarana is one of the pathological processes of Vata vitiation. Avarana is the disturbed movement of Vata due to obstruction by other factors in the body. Vata being aggravated, gets Avrutha by Kapha. Kaphavrutha Vata takes Ashraya (seat)in the Sira (arteries) and Snayu (Nerves) of Manya Pradesha (Nape of the neck) and produces Lakshanas (Symptoms) like Sheetata, Shopha (Swelling), Gaurava (Heaviness), Ruk (Pain) and Chesthastambha (Lack of expression) we can correlate cervical spondylosis with Manyastambha which has dominancy of VataKaphaja Dosha.Cervical spondylosis is a degenerative disease of cervical spine. It is age related degenerative disease but the incidence is increasing day by day due to strenuous activities, faulty postures and long hours desk work cervical spine go through various wear and tear processes because of which the gap between the two vertebrae reduces and the nerve passing through them get compressed and eliciting various symptoms like paraesthesia, radiating pain, numbness in hand, headache, dizziness. Modern medicine has no promising remedy for this disease yet. The general treatment protocol for Avarana is pacification of Vata along with cleansing of channels and treatment of encroaching Dosha. Nasya is considered as the best procedures for disease of head and neck. Ayurvedic classics has mentioned Nasya (earrhines) as the treatment for Urdhva Jatru Gata Vikara (supraclavicular region). Nasya (earrhines) karma has potent effect on Shroto Shodhan (Cleansing of micro channels) and to retard the Dhatukshaya (Depletion of Dhatus).
\end{abstract}

Key Words: Manyasthamba, Cervical spondylosis, Avarana, Nasya Karma.

\section{Introduction}

In today's era, everybody is living a stressful life. Due to lifestyle changes, eating habits, overstress, excessive joint and locomotive travel disorders are very common(1). Approximately $66 \%$ of adults have neck pain and among that $5 \%$ have severe neck pain (2). Manyasthamba (Cervical Spondylosis) is a clinical condition in which back of the neck region becomes stiff and rigid which impairs the movements of the neck. It can be co-related with Cervical spondylosis.

Manyastambha is derived from two different words Manya (Cervical region) and Stambha (Stifness). Amarsingh, the commentator of Bhavprakasha, takes the meaning of Manya as the Sira (Artery) of the posterior side of the neck (3) While the meaning of word Stambha (Stifness) is Niscalikarana (Loss of Normal movement) (Dalhana) and Stambha means stiffness, rigidity, make stiff or immovable (Monier

\section{* Corresponding Author:}

\section{Remesh Chandran T S}

PG Scholar, Department of Kayachikitsa,

Parul Institute of Ayurved,

Parul university, P.O Limda,

Vadodara-391760. India.

Email Id: remeshchandran39@gmail.com william). Manyastambha (Cervical Spondylosis) is the clinical condition in which the back of the neck becomes stiff or rigid and the movements of the neck are impaired. The detailed discussion of Manyastambha was given in almost all texts of Ayurveda (4), (5), (6), (7).

Manyastambha can be correlated with spondylosis in the cervical spine where Intervertebral disk degeneration, cervical spine and bone overgrowth of adjacent vertebrae occurs. Signs and symptoms of cervical spondylosis tend to involve pain, weakness, muscle loss and reflex impairment. The most common symptom is neck pain, worsening with exertion and relieving through rest at the early stages. This pain often radiates to the hands, with the fingers becoming numb due to the extreme compression of the nerves that innervate the upper extremities.

NSAIDs and steroids which is considered to have many side effects such as fluid retention, muscle weakness, Ulcers in the stomach and duodenum etc., has been used for treating cervical spondylosis according to modern medicine. According to Ayurveda, it can be treated by Shamana and Bhrumhana Chikitsa (Nourishment Therapy). It is considered as one of the Urdhvajatrugata Vyadhi (supraclavicular region). So as per treatment point of view Nasya karma said to be an effective management for Manyastambha. Nasya karma 
Charu Bansal et.al., Efficacy of Nasya karma with Karpasasthyadi thailam in the Management of Kaphavrutha Vata

is considered as a comfortable, time efficient and simple procedure without any side effects. So, in this case study Nasya (earrhines) with karpasasthyadi taila along with Thrayodashanga Guggulu was given.

\section{Case Report}

\section{Pradhana Vedana}

Patient complaints of pain in both the upper extremities radiating from neck till the tip of fingers for 15 years. She also complained of numbness and rigidity in the past 2 weeks.

\section{Vedana Vruttanta}

A 53 years old female patient came to the OPD of Parul Ayurveda hospital, who was apparently normal before 15years. As the time passed, due to excess work load without sufficient resting time and irregular postures of sleep, she noticed mild pain in the right shoulder joint but she ignored it. Later on, she felt numbness over the right palmar region. As the schedule of tiring work continued, pain gradually developed in the left shoulder joint, later on, she also felt numbness over the left palmar region. Initially she got relief by taking rest for some time, but gradually the pain did not subside. For these complaints she had taken treatment (modern medicines) but she got temporary relief only. Due to the recurring incidence of the condition her quality of life got worsen and she came to here for better treatment.

\section{Purva Vedana Vruttanta}

- $\mathrm{K} / \mathrm{C} / \mathrm{O} \mathrm{HTN}$ in the past 1 year and is on regular medication.

- No H/O any other major illness or surgical treatment.

\section{Vayakthika Vruttanta}

\begin{tabular}{|l|l|l|}
\hline \multicolumn{1}{|c|}{ Ahara } & \multicolumn{1}{c|}{ Table 1 } & \multicolumn{1}{c|}{ Kihara } \\
Mixed diet. & Sleep- Disturbed & Menopause \\
\hline $\begin{array}{l}\text { Ruksha, Amla, } \\
\text { Tikta Rasa } \\
\text { Pradhan Aahara. }\end{array}$ & $\begin{array}{l}\text { She works about } \\
\text { 8- } 10 \text { hours daily. }\end{array}$ & \\
\hline $\begin{array}{l}\text { Irregular meal } \\
\text { timing. }\end{array}$ & Bowel- irregular & \\
\hline & $\begin{array}{l}\text { Urine-3-5/Day \& } \\
\text { 1-2/Night }\end{array}$ & \\
\hline
\end{tabular}

Table no 1: Showing that Patient was habituated with apathya ahara and vihara (Unwholesome dietry habbit \& regimen) such as ruksha (Dry) amla (Sour) thiktha (Bitter) rasa pradhana ahara (Predominant taste), vishamashana (Irregular untimely food intake). Patient having irregular bowels with disturbed sleep.

\section{Samanya Pareeksha}

- Appearance - Fair

- Pulse rate - 96/ $\mathrm{min}$.

- B.P. $\quad-130 / 90 \mathrm{~mm}$ of $\mathrm{Hg}$.

- R.R. - $16 / \mathrm{min}$.

- Weight - $54 \mathrm{~kg}$.

- Height $\quad-152 \mathrm{~cm}$
- Temperature -Afebrile

- R.S. -Bilateral Air Entry: Clear.

- C.V.S. - $\mathrm{S}_{1} \mathrm{~S}_{2}$ Normal. No abnormal sound

- C.N.S. - Conscious and oriented.

- P/A - Soft. Liver, Kidney, Spleen - not palpable.

\section{Rogi Pariksha}

- Prakruti(Constitution)- Kapha pittala.

- Sara (Composition) - Madhyam.

- Satva(Mental health) - Madhyam.

- Samhanana - Madhyam.

- Kostha - krura.

- Agni (Digestive power)- Vishama.

- Pramana(Measurement)- Madyam

- Aharashkti-Abhyavaranashakti (Intake capacity) -Madhyama

- Jaranashakti(Digestive capacity)-Madhyama

- Vyayamashakthi -Madhyam

- Vaya (Age) - Madhyam

- Jihwa (Tongue) - Sama.

Ashtavidha Pariksha

- Nadi(Pulse)

- Mala(Stool)

- Vatapradhan kapha

- Mutra(Urine)

- Jivha(Tongue)

- Vibhadatha

- Shabda(Speech)

- 5-6 times per day

- Sparsha(Tactilation)

- Saam

- Druk(Eyes)

- Spastha

- Akriti(Anthropomentry) - Madhyam

\section{Clinical Examination of Spine}

- Inspection

- Gait

- No abnormality was seen

- Normal

\section{Investigation}

- $\mathrm{Hb}$

- Urine examination - Sugar-Nil, Albumin-Nil.

\section{Nidana/Diagnosis}

- Nidana(etiology) - Diwaswapna (Day sleep), Asanasthana Vikruti (improper posture of sleep during travelling), Urdwanireekshana (Upward gaze).

- Differential diagnosis - Manyasthamba, Apabahukam, Vishvachi.

- Diagnosis - Manyasthamba.

- Sadhyasadyatha (Prognosis) - Krichra Sadhya (Poor prognosis).

\section{Samprapthi Ghatak}

- Dosha

- Vata - Vyanavata;

Kapha - Shleshmaka kapha

- Dushya

- Agni

- Snayu, rasa

- Srothas

- Jatharagni

- Srothodushti prakara - Sanga

- Udhbhava sathana - Ama Pakwashaya

- Sanchara sthana - Rasayani

- Vyaktha Sthana - Greeva

- Rogamarga - Madhyamarogamarga

- Swabhava - Chirakari 
Internal Medicine Given

- Shadharana choorna for rookshana (Dryness)

- Chitrakadi vati for Deepana and Pachana (Improving digestion)

- Thrayodashanga Guggulu for Shotha Hara (Antiinflammatory)

- Gandharva Hasthadi Kashayam for Anulomana Karma (Downward movement of Vata)

- Shirashooladi Varja rasa for Urdhwajatharugata Vikara (Supraclavicular region)

\section{Procedures done}

Table 2: Showing the Procedures done

\begin{tabular}{l|l|l|}
$\begin{array}{l}\text { Procedure done } \\
\text { Valuka sweda } \\
\text { (Sand poultice) }\end{array}$ & $\begin{array}{c}\text { No of days } \\
\text { Sarvanga }\end{array}$ & $\begin{array}{l}\text { Material used } \\
\text { Sand }\end{array}$ \\
$\begin{array}{l}\text { Abhyanga } \\
\text { (Oelation) }\end{array}$ & days & $\begin{array}{l}\text { Kottamchukkadi } \\
\text { Thailam \& } \\
\text { Murivenna }\end{array}$ \\
\hline Nasya & 8 days & $\begin{array}{l}\text { Karpasasthyadi } \\
\text { thailam }\end{array}$ \\
\hline
\end{tabular}

\section{Result}

The assessment of subjective parameters was done before and after the completion of treatment. The patient's condition improved symptomatically. The assessment of pain was done according to VAS scale.

\section{Subjective Parameters}

Table 3: Showing that severity of stambha (Stiffness) and shoola (Pain) before \& after treatment

\begin{tabular}{|l|l|l|l|l|}
$\begin{array}{l}\text { Sympto } \\
\text { ms }\end{array}$ & Grading & $\begin{array}{l}\text { Sco } \\
\text { re }\end{array}$ & BT & AT \\
\hline Shoola & Nil & 0 & Mild & Absent \\
& $\begin{array}{l}\text { Mild } \\
\text { (Grimace/ } \\
\text { Wince) }\end{array}$ & 1 & & \\
\hline & $\begin{array}{l}\text { Moderate } \\
\text { (Withdrawal) }\end{array}$ & 2 & & \\
\hline & $\begin{array}{l}\text { Severe } \\
\text { (Refusal to } \\
\text { palpate) }\end{array}$ & 3 & & \\
Absent & 0 & Moderate & Absent \\
\hline Stambha & Abst & & \\
\hline
\end{tabular}

Mild (Local 1

rigidity)

Moderate 2

(Rigidity in

regions other

than affected

region)

Severe 3

(Generalized

rigidity)
Visual Analogue Scale (Figure: 1)

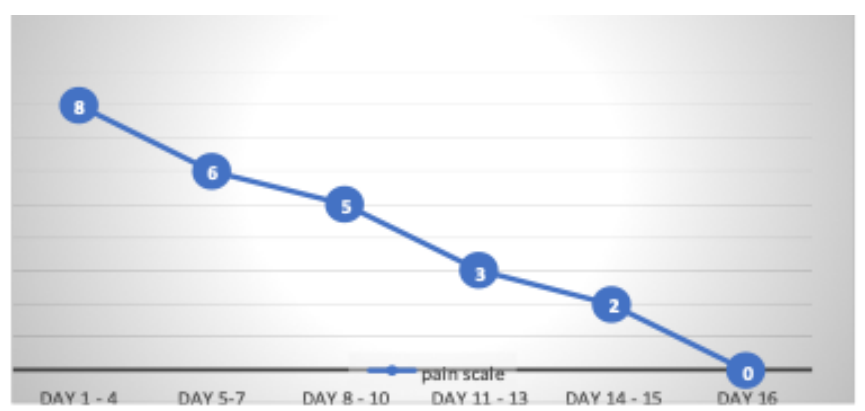

Figure:1: Pain Scale

\section{Probable mode of Action \\ Shaddharana gulika $(8)$ :}

The ingredients are Chitraka (Plumbago zeylanica Linn.), Indrayava (Holarrhena antidysenterica Linn.), Patha (Cissampelos pareira Linn.), Katuka (Picrorhiza kurroa Benth.), Ativisha (Aconitum heterophyllum Wall.ex Royle.) and Abhaya (Terminalia chebula Retz.). The Gulika was powdered to Choorna form and 2 pinches of it was advised to take with ushnajala with a minimum gap of 2 hour. The main intention of starting this yoga was that, it comprises Deepana (Enhance digestion capacity) and Pachana (digestion) properties and also has srothoshodana (cleansing the micro channels) property which helps in reducing the Ama Avastha (Undigested stage). As this yoga has been grouped under Vathavayadhi adhikar by the author himself, the yoga reveals its potential.

\section{Trayodashanga guggulu}

Guggulu is processed with 13 ingredients, So the name Trayodashanga guggulu(9). Ashwagandha (Withania somnifera Linn.), Hapusha (Juniperus communis Linn.), Guduchi (Tinospora cordifolia Willd.), Sathvari (Asparagus racemosus Willd), Gokshuka (Tribulus terrestris Linn.), Devadaru (Cedrus deodara Roxb)., Rasna (Pluchea lanceolata C.B Clarke.), Nagara (Zingiber officinale Linn.), Shatapushpa (Anethum sowa Kurz), Yavani (Trachyspermum ammi Linn.), Shati (Hedychium spicatum Ham.ex.Smith) \& Guggulu (Commiphora wightii Hook.ex Stock) are the contents. The main actions are Vatakaphahara and Deepana (Enhance digestive capacity). Other karmas are Asthiposhaka (Improves patency of bones), Asthimajjagata vata and Shulahara (Analgesic). The constituents like Shatavari (Asparagus racemosus Willd), Ashwagandha (Withania somnifera Linn), and Guduchi (Tinospora cordifolia Willd), are known as rejuvenators and provides strength to Dhatus. Shunthi (Zingiber officinale Linn.) and Ajamoda (Apium graveolens Linn) improves Jatharagni (Digestive fire). Aabha (Vachellia nilotica Linn.) especially acts on Asthidhatwagni. Gritha with its 
Charu Bansal et.al., Efficacy of Nasya karma with Karpasasthyadi thailam in the Management of Kaphavrutha Vata

Yogavahi (which enhances the action \& passes through the minute channels to reach the target site) property helps in better absorption and penetration of the drug. The drugs like Ashwagandha (Withania somnifera Linn), Shatavari (Asparagus racemosus Willd), Guduchi (Tinospora cordifolia Willd), Guggulu (Commiphora wightii Hook.ex Stock), Vriddhadaru (Argyreia nervosa Burm. f), Aabha (Acacia nilotica Linn), Hapusha (Juniperus communis Linn), and Goghritha acts as Balya (Improves strength), Rasayan (Rejuvanating), Vayasthapak (Reduces ageing). The contents of Trayodashanga Guggulu is Guru (Heavy), Snigdha (Unctous), Guna (Quality), Madhur (Sweet) Rasa, Madhur (Sweet) Vipaka and Ushna Virya (Hot potency), which in turn has properties like Dhathu Balya (Improves strength), Pushtikara, shoola prashamana (Analgesics) and Pakahara. One of its main action is on AsthiDhatu (Bone tissue) and Agni Deepana (Improves digestion).

\section{Valuka sweda}

"Stambha Gaurava Sheetaghnam Swedanam Sweda kaaraka"(10) Swedana is said to be the best form of treatment in expelling and destroying the diseases manifested due to morbid Vata and Kapha. In conditions like pain and associated symptoms due to ama (metabolic toxins having a sticky nature, tending to block the transport systems of the body and cause painful conditions), Meda (contaminated or accumulated fat) and kapha (morbid kapha), Ruksha Swedana (dry heat) is indicated.

\section{Gandharva hasthadi kashayam(11)}

Ingredients are Eranda (Ricinus communis Linn.), Chirabilva (Holoptelea integrifolia Planch), Hutasha (Plumbago zeylanica Linn.), Vishwa (Zingiber officinalis Linn.), Pathya (Terminalia chebula Retz.), Punarnava (Boerhavia diffusa Linn.), Yavasa (Alhagi camelorum Fisch.), Bhumitaala (Phyllanthus niruri Linn.) It is vatakaphahara \& Agni Deepana. It mainly acts on vataprakopa in pakvashaya (Lower GIT), by enhancing the Agni (Digestive fire) and controlling the Prakupitha Vata (Agitated vata). Saindhava Lavana is given as Anupana (Adjuvant). It promotes the Agni (Digestive fire) and hence prevents from formation of amaavastha. It acts as best drug of choice for Vatanulomana Karma (Downward movement of vata). It checks the prana vahasrothas and maintains the equilibrium and Amapakvashayagatha Vata (Vata which reside at lower GIT) also.

\section{Shira shooladi vajra rasa(12)}

The ingredients are Parada (Mercury), Gandhaka (Sulphur), Loha - Tamra bhasma, Triphala, Guggulu (Commiphora wightii Hooks.ex Stocks), Kushta(Saussurea lappa C.B. Clarke), Yashtimadhu
(Glycyrrhiza glabra Linn.), Pippali (Piper longum Linn.), Shunti (Zingiber officinalis Linn.), Gokshura (Tribulus terrestris Linn.), Vidanga (Embelia ribes Burm f. ) and Dashamoola. It helps to balance the Vata, Kapha and Pitta Dosha of Urdhvajathru Pradesha (Supra clavicular region). As, dashamoola is the main content, it is kaphavatahara (Decreases vata and kapha dosha) and shothahara (Anti-inflammatory), thus it relives the pain. Tamra is having Lekhana (Scraping) karma it prevents from kaphavriddhi. Parada, Gandhaka and Lohabhasma acts as Rasayana (Rejuvenates) and nourishes the Dhatu.

\section{Chitrakadi vati(13)}

The formulation was named 'Chitrakadivati' due to the presence of the active ingredient Chitraka (Plumbago zeylanica Linn). In Sanskrit classics the word 'Chitrakadi'means 'fire or Agni' since it enhances digestive fire or 'agni' which helps in removing ama and preventing indigestion and other digestive issues that happen due to lack of digestive fire (i.e., Mandagni). Deepana, Pachana, Rechana, Anulomana, Grahi, Shulahara, Shothahara are the main karmas. The herbal ingredients in the potent formulation helps to maintain the equilibrium of Samanavata and Kapha and plays a key role in effectively removing the ama from the body, which in turn leads to Agni Sandushanam (improves the digestive power). This enhances the absorption rate of medicine as well as improving the Dhatwagni. Thus, we can clearly understand the karma in the progress of Chikitsa.

\section{Karpasasthyadi thailam (14)}

It mainly comprise of karpasa (Gossypium arboretum Linn.), Masha (Vigna mungo Linn.) kulatha (Macrotyloma uniflorum Linn.) Bala (Sida cordifolia Linn.), Pippalimoola (Piper Longum Linn.), shigru (Moringa oleifera Lam.), nagara (Zingiber officinalis Linn.) etc. Taila having properties like Snigdha Guna (Unctous), Ushna Veerya (Hot potency) and it is KaphaVata Shamaka and act as Vedana shamaka (Analgesic) and Shothahara (Antiinflammatory), The indication of the Yoga itself states that it is effective in almost all Vatavyadhi and especially on Apabahuka (Cervical spondylosis), Pakshagatha (Hemiplegia) and Arditha (Facial palsy), especially in upper spinal radiculopathy. It possesses Balya (Strengthen) and Bhramana (Nourishment) karma, which can be given in degenerative disorders. Most of the ingredients of Karpasthyadi Taila is Katurasa Pradhana (Pungent taste), but the influence of Snighda (Unctous) \& Guru (Heaviness) guna of taila, Ushna guna (Hot potency) and Veerya (potency) of the dravyas it subsides the Prakupita Vata (Agitated vata), i.e., the Ushan Veerya (Hot potency) of the ingredients 
of Thailam will subside the Sheeta Guna (cold potency) of Vata and the patient will relief from Shoola (pain) and Sthamba (stiffness) conditions.

\section{Discussion}

Manyastambha (Cervical spondylosis) is mainly degenerative disease, it can be included under Asthi-Majja Gatavata (Vata which resides at bone \& bone marrow) as it involves Vata, Asthi (Bone), and Sandhi Dushti (Depletion of joints). Nidana Sevana (etiology) causes Vata Prakopa (Agitates vata) and gets Avrutha (Covering) by kapha, which in turn does Sthabdatha (Stifness) of 14 Manya Siras (veins of cervical region) situated in the back of neck and results in Manyastambha (Cervical spondylosis). In the initial stage we can accept the involvement of Kapha in Manyastambha (Cervical spondylosis) but in the later stages, we find the compression of nerve root due to osteophytic changes producing different signs and symptoms which are collectively termed as Manyastambha. It can be attributed to the role of Vata Dosha and there is minimal or no involvement of Kapha.

Acharya Vagbhata's quotes that "Naasa $\mathrm{Hi}$ Shirasodwaram" (15), i.e., nose is the easiest and closest opening for conveying the potency of medicines to the cranial cavity. The Nasya Dravya acts by reaching 'Sringataka Marma' (Vital point at forehead) from where it spreads into various Strotas (vessels and nerves) and brings out vitiated Dosha from the head.

The incorporation of medications into the brain can be understood by the following three phenomena (16)

- By general blood circulation after mucous membrane absorption.

- Direct pooling into the brain's venous sinuses through lower ophthalmic veins.

- Absorption in the cerebrospinal fluid.

The nasal cavity opens directly into the frontal, maxillary, and sphenoidal air sinuses, the transient retention of the drug in the nasopharynx and the suction causes the oozing of the drug material in the air. These sites have rich vessels of blood to the brain and meninges through existing bone foramens. Therefore, in this path there are better chances of drug absorption. According to Vagbhata's narration, the drug administered enters the paranasal sinuses. It is Shringhataka, which extends the visual veins and the other veins. In this context, it appears that the mention of the shringataka is more appropriate. The first coverage of nerve fiber made up of lipid material is Myelin sheath. For lipid materials and materials that are fat-soluble, the blood brain barrier is highly permeable and can therefore easily pass through the blood brain barrier and take action. The lipid contents of
Karpasasthyadi Thailam can easily be transferred through the blood brain barrier, and effective principles can reach certain levels in the nervous system to exert their properties.

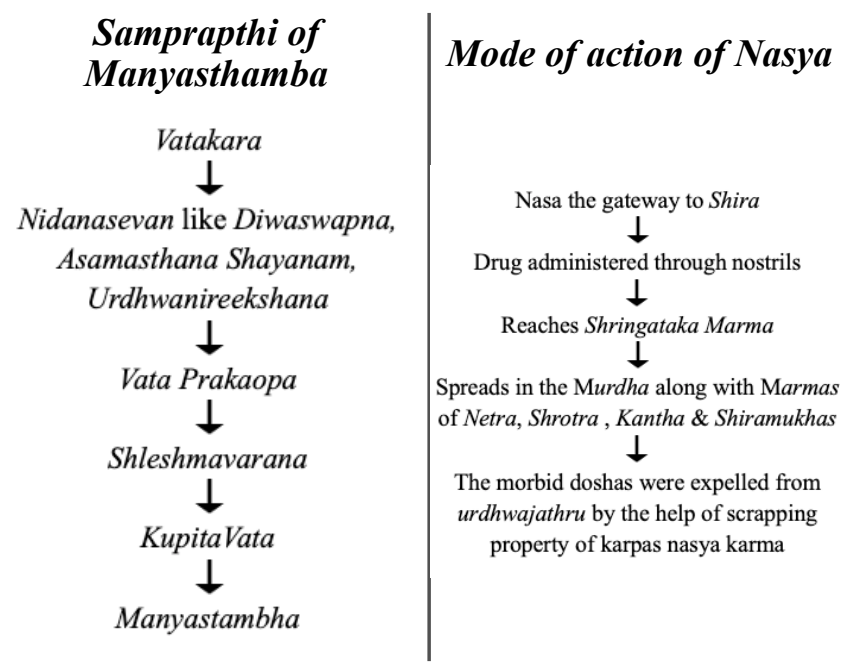

\section{Result}

The patient has obtained tremendous pain and stiffness relief within 16 days of treatment and showed substantial improvement. The assessment of VAS pain scale has resulted in significant reduction in pain. The above visual analogue scale indicates the patient's pain level of $1^{\text {st }}, 5^{\text {th }}, 8^{\text {th }}, 11^{\text {th }}, 14^{\text {th }} \& 16^{\text {th }}$ day respectively. On the first day the pain grade was 8 (severe pain). On the $5^{\text {th }}$ day the pain grade become 6 (moderate pain). The $14^{\text {th }}$ day of assessment shows that the symptoms have considerably reduced and the VAS scale has become 3 (Mild pain). The follow up on $16^{\text {th }}$ day has made the pain scale to 0 (No pain) and on the $16^{\text {th }}$ day the patient had no pain or any other symptoms and was discharged from the hospital. (Figure: 1).

\section{Conclusion}

Nasya Karma's plays an important role in handling this situation. As a Brihmana (Nourishes) and Vata-Kapha Hara Yoga, Karpasasthyadi Thailam, it's been given as Nasya. As the case showed, marked relief from symptoms such as pain and tenderness were observed within 2 days of treatment completion. It can be concluded that this treatment approach can be used as a standard procedure taking into account its efficacy and safe clinical regime for Manyasthamba.

\section{Reference}

1. Domino frank, The 5-minute Clinical consult, 2008. Philadelphia: Lippinocott Wiilliams and Wilkins, page no-240.

2. Birse TM \& Lander J, Prevalence of chronic pain; Can J Public Health. 1998; 89:129-131.

3. Bulusu Sitaram commentator on BahavaPrakasha Madhyama kandha of bhavamishra, 
Bhavaprakasham, vol 2, Varanasi, Chaukhamba Orientalia, 24/25 page 271.

4. Sharma P V. Charaka Samhita of Agnivesa. 1st edition. Varanasi; Chaukhamba Orientalia publishers; 2009. 465p.

5. Sharma P V. Susruta Samhita of Acharya Susruta. $1^{\text {st }}$ edition. Varanasi; Chaukhamba Vishwabharati publishers; 2009. 14p.

6. Murthy K R S. Ashtanga Hrudaya of Vagbhata. 1st edition. Varanasi; Chaukhamba Krishnadasa academy; 2016. 152p.

7. Murthy K R S. Ashtanga Hrudaya of Vagbhata. 1 ${ }^{\text {st }}$ edition. Varanasi; Chaukhamba Krishnadasa academy; 2016. 152p.

8. Rao G P. Bhaishajya Ratnavali of Kaviraj. 1 ${ }^{\text {st }}$ edition. Varanasi; Chaukhamba Orientalia; 2003. $704 p$.

9. Rao G P. Bhaishajya ratnavali of Kaviraj. 1st edition. Varanasi; Chaukhamba Orientalia; date. $714 \mathrm{p}$.
10. Sharma P V. Charaka Samhita of Agnivesa. $1^{\text {st }}$ edition. Varanasi; Chaukhamba Orientalia; 2010. $150 \mathrm{p}$.

11. Krishnana Vidhyar $\mathrm{K}$ R, Gopalapilla $\mathrm{S}$ A. Sahasrayoga. $35^{\text {th }}$ edition. Alappuzha; Vidhyarambam publications; 78p.

12. Rao G P. Bhaishajya ratnavali of Kaviraj. 1 ${ }^{\text {st }}$ edition. Varanasi; Chaukhamba orientalia; date. $537 \mathrm{p}$.

13. Sharma P V. Charaka Samhita of Agnivesa. 1st edition. Varanasi; Chaukhamba orientalia publishers; 2009. 257p.

14. Krishnana Vidhyar K R, Gopalapilla S A. Sahasrayoga. $35^{\text {th }}$ edition. Alappuzha; Vidhyarambam publications; $278 \mathrm{p}$.

15. Sreekumar T. Ashtanga Hrudaya of Vagbhata. $4^{\text {th }}$ edition.Trishur. Harisree hospital publications; $103 p$.

16. Watkinson John, Gilbert Ralph. Stella and Marans text book of Head and Neck Surgery and oncology. $5^{\text {th }}$ ed. Oxford publication; 2012. 757-59p. 